\title{
Short Story about a Squirrel's Tail
}

By KEN LIDDELL

\author{
(From "Furrows and Foothills," Calgary Herald)
}

This is a short tale about a squirrel's tail.

The squirrel, just a wee, wee, squirrel, was one of a family of quintuplets and the baby squirrels were born, of all places, in a bureau drawer.

One of the baby squirrels was rather stupid and was always falling out of the drawer and the people who lived in the room and shared the bureau with the squirrels were always putting him; or maybe it was her, back in the drawer.

The bureau is in quarters used by employees at the Gateway Inn, a restaurant just outside the entrance to Banff Park, but the family of squirrels has flown the coop, or rather the crib.

Before the family was born the mama squirrel loved to play on the roof of the building, which is a log structure, and when her hospitalization neared she somehow made her way inside the building from the roof and nestled down in the bureau drawer.

No squirrel ever had more midwives. Mrs. Katherine Hicks, who runs the restaurant, and some 10 employees watched over the family for six weeks. They noticed the babies at birth were about the size of the second joint of a person's finger, and that it was 28 days before they opened their eyes.

When time came to remove the babies to their outside home, which was a spot in the attic, the mother carried them one by one in her mouth. She didn't seem too fussy about the attention the children received when in the drawer, either. When the curious went close she sat on the window and scolded.

But one of the most interesting observations was made by Mrs. Ruby Pfiefer who happened to be up and about at six o'clock one morning.

She heard the mother scolding one of the children. As she watched she saw the mother trying to train the baby to keep its tail up ... and curved.

Mrs. Pfiefer is no particular authority on squirrels, but she is quite sure that is what the mother was doing. And like mothers often do, she was getting a little impatient with the child. Maybe it was the stupid one.

Mrs. Pfiefer said it was a scene the average person would see once in a lifetime, if that often.

The mother, said Mrs. Pfiefer, would slap the baby under the tummy with one paw and at the same time would bring the other paw down in a smart clip to the back just in front of the tail.

The result, said Mrs. Pfeifer, was something of a reflex action. Something like striking a person's knee when the legs are crossed.

Anyway, up popped the tail, with a curve in it.

\section{AUTUMN OBSERVATIONS}

(Continued from Page 18)

black and orange, Magnolias with a conspicuous white band across the tail, and the olive-green of the Tennessee, Orange-crowned, Cape May, Chestnut-sided and Nashville Warblers.

The time had gone quickly and it was soon time to go home. Overhead a flock of Cranes was winging its way southward. Several flocks of Cranes and Canada Geese passed over that morning. Crows had been seen flocking together on the fields.

Summer has passed quickly and soon the Redpolls will be back. Each fighting to get his share of weedseeds from the feeding tray or the trap. Evening Grosbeaks will come looking for sunflower seeds. Bohemian Waxwings will eat the Chokecherries we have picked and dried for them. Snow Buntings will again be drifting over the fields and then we will know it is winter! 